\title{
UPAYA MENINGKATKAN KEAKTIFAN DAN HASIL BELAJAR MATEMATIKA SISWA KELAS 5 MELALUI MODEL PEMBELAJARAN KOOPERATIF TIPE TEAMS GAMES TOURNAMENT (TGT) DI SEKOLAH DASAR VIRGO MARIA 1 AMBARAWA SEMESTER II TAHUN PELAJARAN 20132014
}

\author{
Vian Anggraeni \\ Alumni Program Studi S1 PGSD \\ FKIP - Universitas Kristen Satya Wacana \\ Wasitohadi \\ wasitohadiuksw@gmail.com \\ Program Studi S1 PGSD \\ FKIP - Universitas Kristen Satya Wacana
}

\begin{abstract}
ABSTRAK
Pembelajaran matematika di Sekolah Dasar (SD) pada umumnya masih diajarkan oleh guru dengan metode yang konvensional melalui ceramah. Hal tersebut menyebabkan siswa menjadi jenuh dan cenderung pasif pada saat pembelajaran di kelas. Ketidaktepatan guru dalam memilih metode dan media pembelajaran juga akan berakibat pada rendahnya keaktifan dan hasil belajar siswa. Oleh sebab itu, maka diperlukan adanya perbaikan pembelajaran tersebut untuk meningkatkan keaktifan dan hasil belajar siswa. Penelitian ini bertujuan untuk meningkatkan keaktifan dan hasil belajar matematika siswa kelas 5 dengan menggunakan model pembelajaran kooperatif tipe Teams Games Tournament (TGT) di SD Virgo Maria 1 Ambarawa pada semester II tahun pelajaran 2013/2014.

Jenis penelitian yang digunakan adalah Penelitian Tindakan Kelas. Model penelitian ini mengadopsi model PTK Kurt Lewin yang terdiri dari 4 tahap, yaitu perencanaan, pelaksanaan tindakan, observasi dan refleksi. Penelitian ini terdiri dari dua siklus. Tiap siklus terdiri dari tiga pertemuan. Subjek dalam penelitian ini adalah siswa kelas 5 SD Virgo Maria 1 Ambarawa yang berjumlah 26 siswa. Teknik pengumpulan data berupa teknik tes dan non tes. Teknik tes berupa soal evaluasi akhir dan non tes berupa observasi serta dokumentasi. Kriteria keberhasilan dalam penelitian ini yaitu jika nilai rata-rata siswa kelas 5 mencapai atau melebihi Kriteria Ketuntasan Minimal (KKM) yaitu $\geq 65$. Teknik analisis data yang digunakan adalah analisis ketuntasan dan analisis komparatif hasil belajar.

Hasil penelitian menunjukkan bahwa melalui model pembelajaran kooperatif tipe TGT dapat meningkatkan keaktifan dan hasil belajar matematika siswa kelas 5 SD Virgo Maria 1 Ambarawa. Ini dapat dilihat dari skor awal aktivitas belajar siswa pada siklus I adalah 67 dengan rata-rata 3,2 (79,8\%); pada siklus II meningkat menjadi 76 dengan ratarata 3,6 (90,5\%). Hasil belajar matematika siswa kelas 5 juga mengalami peningkatan ratarata kelas. Pada tes pra siklus 60,7; tes siklus I 64,2; dan tes siklus II menjadi 74,5. Siswa yang tuntas belajar, pada tes pra siklus $46,2 \%$; siklus I 46,2\%; dan pada siklus II sebanyak $61,5 \%$. Ini berarti dari segi persentase ketuntasan belum dapat memenuhi indikator kinerja yang diharapkan yaitu siswa tuntas dengan persentase $80 \%$.
\end{abstract}

Kata Kunci: Model Pembelajaran Kooperatif tipe TGT, keaktifan siswa, hasil belajar matematika. 


\section{PENDAHULUAN}

\section{Latar Belakang Masalah}

Pembelajaran matematika merupakan salah satu mata pelajaran wajib yang diajarkan di Sekolah Dasar. Menurut Wahyudi dan Kriswandani (2010:1) "Matematika merupakan salah satu mata pelajaran yang diberikan di pendidikan dasar karena matematika sangat penting digunakan dalam kehidupan sehari-hari”. Hampir semua mata pelajaran di Sekolah Dasar menerapkan perhitungan dalam matematika, oleh sebab itu dalam pengajaran mata pelajaran matematika diberikan alokasi waktu yang cukup banyak dibandingkan dengan mata pelajaran yang lainnya. Dalam pembelajaran matematika di SD ternyata masih banyak sekali hambatan atau kesulitan-kesulitan yang terjadi, diantaranya anggapan para siswa bahwa matematika adalah mata pelajaran yang paling ditakuti dan sulit dibandingkan dengan mata pelajaran yang lainnya.

Mata pelajaran matematika di Sekolah Dasar pada umumnya masih diajarkan oleh guru kepada siswa menggunakan cara yang konvensional, dimana proses pembelajaran hanya berpusat pada guru dan disampaikan dengan metode ceramah. Akibatnya dalam proses pembelajarannya siswa menjadi tidak aktif, merasa jenuh bahkan akan kesulitan dalam memahami konsep matematika secara optimal.

Salah satu cara mengaktifkan belajar siswa adalah dengan memberikan berbagai pengalaman belajar bermakna yang bermanfaat bagi kehidupan siswa dengan memberikan rangsangan tugas, tantangan, memecahkan masalah, atau mengembangkan pembiasaan agar dalam dirinya tumbuh kesadaran bahwa belajar menjadi kebutuhan hidupnya dan oleh karena itu perlu dilakukan sepanjang hayat. Ada baiknya setiap guru mengetahui tipe belajar setiap siswa agar kegiatan pembelajaran yang diselenggarakan dapat mencapai tujuan secara efektif dan efisien. Pengetahuan tipe belajar siswa ini akan bermanfaat bagi guru dalam menerapkan model pembelajaran yang tepat.

Model pembelajaran kooperatif merupakan salah satu strategi mengajar yang sesuai dengan fitrah manusia sebagai makhluk yang penuh ketergantungan dengan orang lain, mempunyai tujuan dan tanggung jawab bersama, pembagian tugas dan rasa senasib. Pada saat siswa belajar secara kooperatif, siswa dilatih dan dibiasakan untuk saling berbagi (sharing) pengetahuan, pengalaman, tugas, dan tanggung jawab. Saling membantu dan berlatih berinteraksi, berkomunikasi dan bersosialisasi karena kooperatif adalah miniatur hidup bermasyarakat dan belajar menyadari kekurangan dan kelebihan masing-masing.

Pembelajaran kooperatif dapat mengubah pembelajaran yang hanya berpusat pada guru menjadi aktivitas pembelajaran dalam kelompok-kelompok kecil dimana peran guru adalah sebagai pengelola. Dengan demikian, siswa akan menjadi lebih aktif dan pembelajaran menjadi tidak monoton. Selain itu, siswa akan terlatih untuk belajar menyelesaikan berbagai masalah bahkan permasalahan yang dianggap sulit sekalipun. Menurut pendapat beberapa ahli, model pembelajaran kooperatif dapat memberikan masukan yang berarti bagi sekolah, guru, terlebih para siswa dalam meningkatkan keaktifan dan hasil belajar siswa. Berdasarkan dari hal tersebut, maka peneliti ingin melihat pembelajaran kooperatif melalui tipe TGT. 
Pembelajaran kooperatif tipe TGT dapat membuat siswa aktif bekerja dalam kelompok serta lebih bertanggung jawab pada tugas-tugas yang diberikan oleh guru. Penerapan model pembelajaran tersebut adalah dengan cara mengelompokkan siswa secara heterogen, tugas untuk masing-masing kelompok pun bisa sama atau berbeda. Setelah memperoleh tugas, setiap kelompok bekerja sama dalam bentuk kerja individual dan diskusi. Dalam dinamika kelompok diusahakan kohesif dan kompak serta tumbuh rasa kompetisi antar kelompok, suasana diskusi nyaman dan menyenangkan seperti dalam kondisi permainan (games) yaitu dengan cara guru bersikap terbuka, ramah, lembut, dan santun. Setelah selesai kerja kelompok, sajikan hasil kelompok sehingga terjadi diskusi kelas.

Hasil pembelajaran sebelum dilakukan perbaikan diketahui bahwa dari 26 siswa, hanya ada 12 siswa $(46,2 \%)$ yang telah mencapai ketuntasan dalam materi pecahan dengan nilai rata-rata kelas hanya 60,7 sehingga masih belum mencapai ketuntasan yang diharapkan yaitu nilai rata-rata klasikal mencapai atau melebihi 65. Rendahnya hasil belajar siswa khususnya pada materi pecahan menjadi masalah yang perlu segera diatasi. Penyebab utama rendahnya pemahaman serta aktivitas siswa terhadap mata pelajaran matematika terjadi karena ketidaktepatan guru dalam memilih metode pembelajaran. Dengan demikian maka perlu adanya perbaikan pembelajaran untuk meningkatkan aktivitas serta hasil belajar siswa dalam KBM, yaitu melalui Penelitian Tindakan Kelas yang sangat besar manfaatnya. PTK adalah perbaikan praktek pembelajaran dengan sasaran akhir memperbaiki hasil belajar siswa sehingga kesalahan dalam proses pembelajaran akan segera dianalisa dan diperbaiki (Raka Joni, 2008). Berdasarkan uraian tersebut, penulis tertarik untuk melakukan penelitian dengan judul "Upaya Meningkatkan Keaktifan dan Hasil Belajar Matematika Siswa Kelas 5 Melalui Model Pembelajaran Kooperatif Tipe TGT di Sekolah Dasar Virgo Maria 1 Ambarawa Semester II Tahun Pelajaran 2013 / 2014”.

\section{Tujuan dan Manfaat Penelitian}

Penelitian ini bertujuan untuk meningkatkan keaktifan dan hasil belajar matematika siswa kelas 5 di SD Virgo Maria 1 Ambarawa semester II tahun pelajaran 2013/ 2014 dengan menggunakan model pembelajaran kooperatif tipe TGT. Sedangkan manfaatnya, meliputi manfaat teoritis dan manffat praktis. Secara teoritis, hasil penelitian ini diharapkan dapat memperkokoh dan mendukung teori yang sudah ada terkait dengan model pembelajaran kooperatif tipe TGT dalam rangka peningkatan keaktifan dan hasil belajar matematika. Sementara manfaat praktisnya, bagi siswa: memberikan pengalaman belajar yang menarik melalui pembelajaran kooperatif tipe TGT karena siswa dilibatkan secara langsung dalam kegiatan pembelajaran, sehingga dapat meningkatkan keaktifan dan hasil belajar matematika siswa. Bagi guru, sebagai acuan untuk lebih meningkatkan kreativitas pembelajaran melalui penggunaan variasi model pembelajaran yang menarik dan menyenangkan, khususnya pada mata pelajaran matematika sebagai salah satu usaha untuk meningkatkan keaktifan dan hasil belajar siswa.

\section{KAJIAN PUSTAKA}

Pembelajaran matematika masih diajarkan oleh kebanyakan guru di SD dengan cara konvensional dan belum ada 
penerapan model pembelajaran yang inovatif sehingga mengakibatkan rendahnya aktivitas belajar dan hasil belajar siswa. Oleh karena itu perlu dirancang suatu pembelajaran yang memungkinkan siswa untuk aktif baik secara mental maupun fisik guna meningkatkan keaktifan dan hasil belajar matematika siswa. Salah satu model pembelajaran yang dirancang untuk dapat memperbaiki masalah tersebut adalah model pembelajaran kooperatif tipe TGT.

\section{Model Pembelajaran Kooperatif}

Menurut Agus Suprijono (2009:46) model pembelajaran adalah pola yang digunakan dalam merencanakan pembelajaran di kelas maupun tutorial. Joyce dalam Agus Suprijono (2009:46) mengatakan bahwa fungsi dari model pembelajaran yaitu guru dapat membantu siswa mendapatkan informasi, ide, ketrampilan, cara berpikir, dan mengekspresikan ide-ide. Akibat dari penggunaan model pembelajaran tidak hanya bagaimana siswa tersebut dapat memperoleh pengetahuan tetapi bagaimana siswa juga dapat meningkatkan kemampuannya dalam memahami ilmu pengetahuan yang didapatkannya.

Nurhadi (2003:60) mengatakan bahwa pembelajaran kooperatif adalah suatu sistem yang didasarkan pada alasan bahwa manusia sebagai makhluk individu yang berbeda satu sama lain sehingga konsekuensi logisnya manusia harus menjadi makhluk sosial, makhluk yang berinteraksi dengan sesama. Menurut Lie (2002:40) pembelajaran kooperatif merupakan model pembelajaran yang menggunakan sistem pengelompokan tim kecil yaitu antara yang mempunyai latar belakang kemampuan akademik, jenis kelamin, ras, atau suku bangsa yang berbeda. Sejalan dengan hal tersebut, pengelompokan heterogenitas merupakan ciri-ciri yang menonjol dalam model pembelajaran kooperatif.

Tujuan penting dari pembelajaran kooperatif adalah untuk mengajarkan kepada siswa keterampilan kerja sama dan kolaborasi. Keterampilan ini amat penting untuk dimiliki di dalam masyarakat dimana banyak kerja orang dewasa sebagian besar dilakukan dalam organisasi yang saling bergantung satu sama lain dan dimana masyarakat secara budaya semakin beragam (Ibrahim, dkk. 2000:9). Menurut Slavin (1994) tujuan dari pembelajaran kooperatif adalah menciptakan situasi dimana keberhasilan individu ditentukan atau dipengaruhi oleh keberhasilan kelompoknya.

Menurut Sadker dan Sadker (Huda, 2011) 4 manfaat model pembelajaran kooperatif yaitu siswa yang diajari dalam struktur-struktur kooperatif akan memperoleh hasil pembelajaran yang lebih tinggi khususnya bagi siswa Sekolah Dasar untuk mata pelajaran matematika, siswa yang berpartisipasi dalam pembelajaran kooperatif akan memiliki sikap harga diri yang lebih tinggi dan motivasi yang besar untuk belajar, siswa menjadi lebih peduli pada teman-temannya, dan di antara mereka akan terbangun rasa ketergantungan yang positif, dan meningkatkan rasa penerimaan siswa terhadap teman-temannya yang berasal dari latar belakang ras dan etnik yang berbeda.

\section{Model Pembelajaran TGT}

TGT pada mulanya dikembangkan oleh David DeVries dan Keith Edwards. Dalam TGT, para siswa dikelompokkan dalam tim belajar yang terdiri atas empat orang yang heterogen. Guru menyampaikan pelajaran, lalu siswa bekerja dalam tim 
mereka untuk memastikan bahwa semua anggota tim telah menguasai pelajaran (Slavin, 2008). Secara umum, pembelajaran kooperatif tipe TGT memiliki prosedur belajar yang terdiri atas siklus regular dari aktivitas pembelajaran kooperatif. Games Tournament dimasukkan sebagai tahapan review setelah siswa bekerja dalam tim. Nur \& Wikandari (2000) menjelaskan bahwa TGT telah digunakan dalam berbagai macam mata pelajaran, dan paling cocok digunakan untuk mengajar tujuan pembelajaran yang dirumuskan dengan tajam dengan satu jawaban benar, seperti perhitungan dan penerapan berciri matematika, dan fakta-fakta serta konsep IPA.

Menurut Slavin (2010), model pembelajaran kooperatif tipe TGT adalah salah satu tipe atau model pembelajaran kooperatif yang mudah diterapkan, melibatkan aktivitas seluruh siswa, melibatkan peran siswa sebagai tutor sebaya dan mengandung permainan dan reinforcement. TGT menggunakan turnamen akademik, dan menggunakan kuis-kuis dan sistem skor kemajuan individual, di mana siswa berlomba sebagai wakil tim mereka dengan anggota tim lain untuk memperoleh skor tertinggi.

Model pembelajaran TGT adalah salah satu tipe atau model pembelajaran kooperatif yang mudah diterapkan, melibatkan aktivitas seluruh siswa tanpa harus ada perbedaan status, melibatkan peran siswa sebagai tutor sebaya dan mengandung unsur permainan dan reinforcement. Aktivitas belajar dengan permainan yang dirancang dalam pembelajaran kooperatif model TGT memungkinkan siswa dapat belajar lebih rileks disamping menumbuhkan tanggung jawab, kejujuran, kerja sama, persaingan sehat dan keterlibatan belajar.
Secara teknis, Slavin (2008) mengemukakan empat langkah utama dalam pembelajaran dengan teknik TGT yang merupakan siklus regular dari aktivitas pembelajaran, sebagai berikut:

a. Step 1: Pengajaran, pada tahap ini guru menyampaikan materi pelajaran.

b. Step 2: Belajar Tim, para siswa mengerjakan lembar kegiatan dalam tim mereka untuk menguasai materi.

c. Step 3: Turnamen, para siswa memainkan game akademik dalam kemampuan yang homogen, dengan meja turnamen tiga peserta (kompetisi dengan tiga peserta).

d. Step 4: Rekognisi Tim, skor tim dihitung berdasarkan skor turnamen anggota tim, dan tim tersebut akan direkognisi apabila mereka berhasil melampaui kriteria yang telah ditetapkan sebelumnya.

Adapun sintaks pembelajaran model TGT dapat disajikan seperti berikut ini.

a. Guru menyampaikan semua tujuan pembelajaran secara umum yang ingin dicapai dan memotivasi siswa belajar

b. Guru menyajikan materi pelajaran kepada siswa dengan cara demonstrasi lewat bahan bacaan/LKS

c. Guru membagi siswa membagi siswa menjadi kelompok secara heterogen, masing-masing kelompok terdiri dari 45 orang

d. Guru membagi siswa kedalam beberapa meja turnamen

e. Guru membagi soal evaluasi kepada masing-masing kelompok turnamen

f. Guru memberikan penghargaan kepada setiap kelompok yang memiliki poin tertinggi

\section{Keaktifan Siswa}

Secara harafiah keaktifan berasal 
dari kata aktif yang berarti sibuk, giat (Kamus Besar Bahasa Indonesia, 1988: 17). Aktif mendapat awalan ke- dan akhiran-an, sehingga menjadi keaktifan yang mempunyai arti kegiatan atau kesibukan. Jadi, keaktifan belajar adalah kegiatan atau kesibukan peserta didik dalam kegiatan belajar mengajar di sekolah maupun di luar sekolah yang menunjang keberhasilan belajar siswa. Keaktifan siswa dalam proses pembelajaran akan menyebabkan interaksi yang tinggi antara guru dengan siswa ataupun dengan siswa itu sendiri. Hal ini akan mengakibatkan suasana kelas menjadi segar dan kondusif, dimana masing-masing siswa dapat melibatkan kemampuannya semaksimal mungkin. Aktivitas yang timbul dari siswa akan mengakibatkan pula terbentuknya pengetahuan dan keterampilan yang akan mengarah pada peningkatan prestasi. Keaktifan siswa selama proses belajar mengajar merupakan salah satu indikator adanya keinginan atau motivasi siswa untuk belajar. Siswa dikatakan memiliki keaktifan apabila ditemukan ciri-ciri perilaku seperti: sering bertanya kepada guru atau siswa lain, mau mengerjakan tugas yang diberikan guru, mampu menjawab pertanyaan yang diberikan, senang diberi tugas belajar, dan lain sebagainya (Rosalia, 2005:4).

Menurut Muhibbin Syah (2012: 146) bahwa faktor yang mempengaruhi keaktifan belajar peserta didik dapat digolongkan menjadi tiga macam, yaitu faktor internal (faktor dari dalam peserta didik), faktor eksternal (faktor dari luar peserta didik), dan faktor pendekatan belajar (approach to learning). Secara sederhana faktor-faktor yang dapat mempengaruhi keaktifan belajar peserta didik tersebut dapat diuraikan sebagai berikut.

1. Faktor internal peserta didik, merupakan faktor yang berasal dari dalam diri peserta didik itu sendiri, yang meliputi:

a. aspek fisiologis, yaitu kondisi umum jasmani dan tonus (tegangan otot) yang menandai tingkat kebugaran organorgan tubuh dan sendi-sendinya, dapat mempengaruhi semangat dan intensitas peserta didik dalam mengikuti pelajaran.

b. aspek psikologis, belajar pada hakikatnya adalah proses psikologis. Oleh karena itu, semua keadaan dan fungsi psikologis tentu saja mempengaruhi belajar seseorang. Adapun faktor psikologis peserta didik yang mempengaruhi keaktifan belajarnya adalah sebagai berikut: (1) intelegensi, tingkat kecerdasan atau intelegensi (IQ) peserta didik tidak dapat diragukan lagi dalam menentukan keaktifan dan keberhasilan belajar peserta didik. Ini bermakna bahwa semakin tinggi tingkat intelegensinya maka semakin besar peluangnya untuk meraih sukses, begitu juga sebaliknya; (2) sikap, adalah gejala internal yang berdimensi afektif berupa kecenderungan untuk mereaksi atau merespon dengan cara yang relatif tetap terhadap objek orang, barang, dan sebagainya, baik secara positif maupun negatif; (3) bakat, adalah potensi atau kecakapan dasar yang dibawa sejak lahir yang berguna untuk mencapai prestasi sampai ke tingkat tertentu sesuai dengan kapasitas masing-masing; (4) minat, adalah kecenderungan atau kegairahan yang tinggi atau keinginan yang besar terhadap sesuatu; dan (5) motivasi, adalah kondisi psikologis yang mendorong seseorang untuk melakukan sesuatu. Jadi motivasi belajar adalah kondisi psikologis yang mendorong seseorang untuk belajar. 
2. Faktor eksternal peserta didik, merupakan faktor dari luar siswa yakni kondisi lingkungan di sekitar siswa. Adapun yang termasuk dari faktor eksternal diantaranya adalah: (a) lingkungan sosial, yang meliputi: para guru, para staf administrasi, dan teman-teman sekelas; serta (b) lingkungan non sosial, yang meliputi: gedung sekolah dan letaknya, rumah tempat tinggal keluarga peserta didik dan letaknya, alat-alat belajar, keadaan cuaca dan waktu belajar yang digunakan peserta didik.

3. Faktor pendekatan belajar, merupakan segala cara atau strategi yang digunakan peserta didik dalam menunjang keefektifan dan efisiensi proses pembelajaran materi tertentu.

\section{Hasil Belajar Siswa}

Kata hasil belajar sering disebut prestasi belajar. Kata prestasi berasal dari Belanda yaitu "Prestatie" kemudian dalam bahasa Indonesia disebut prestasi yang artinya hasil usaha. Kata prestasi juga berarti kemampuan, ketrampilan, sikap seorang dalam menyelesaikan sesuatu (Arifin, 1999:78). Hasil belajar merupakan perubahan perilaku yang diperoleh setelah mengalami aktivitas belajar (Anni, 2004: 4).

Hasil belajar merupakan hal yang sebenarnya dapat dipandang dari dua sisi, yaitu sisi siswa dan dari sisi guru. Dari sisi siswa, hasil belajar merupakan tingkat perkembangan mental yang lebih baik bila dibandingkan pada saat sebelum belajar. Menurut Bloom dalam Siregar (2010) tingkat perkembangan mental tersebut terwujud pada jenis-jenis ranah kognitif, afektif, dan psikomotor. Dilihat dari sisi guru, hasil belajar merupakan saat terselesaikannya bahan pelajaran. Hasil juga bisa diartikan adalah bila seseorang telah belajar akan terjadi perubahan tingkah laku pada orang tersebut, misalnya dari tidak tahu menjadi tahu, dan dari tidak mengerti menjadi mengerti. Menurut Woordworth (dalam Ismihyani, 2000) hasil belajar merupakan perubahan tingkah laku sebagai akibat dari proses belajar. Woordworth juga mengatakan bahwa hasil belajar adalah kemampuan aktual yang diukur secara langsung. Hasil pengukuran belajar inilah akhirnya akan mengetahui seberapa jauh tujuan pendidikan dan pengajaran yang telah dicapai.

Slameto (2003: 54-72) menyatakan bahwa faktor-faktor yang mempengaruhi hasil belajar digolongkan menjadi dua, yaitu:

\section{Faktor Internal}

Faktor internal adalah faktor yang berasal dari diri siswa. Faktor internal ini terdiri dari tiga faktor diantaranya: a) Jasmaniah, misalnya: kesehatan dan cacat tubuh. b) Psikologis, misalnya: intelegensi, perhatian, minat, bakat, motif, kematangan, dan kesiapan. c) Kelelahan

\section{Faktor Eksternal}

a. Keluarga, misalnya: cara orang tua mendidik, relasi antar anggota keluarga, suasana rumah, keadaan ekonomi keluarga, pengertian orang tua, dan latar belakang kebudayaan.

b. Sekolah, misalnya: metode mengajar, kurikulum, relasi guru dengan siswa, relasi siswa dengan siswa, disiplin sekolah, alat pelajaran, waktu sekolah, standar pelajaran di atas ukuran, keadaan gedung, model pembelajaran, metode belajar, dan tugas rumah.

c. Masyarakat, misalnya: kegiatan-kegiatan siswa dalam masyarakat, media massa, teman bergaul, bentuk kehidupan masyarakat. 
Menurut Aqib (2003) salah satu komponen yang berpengaruh dalam rangka peningkatan mutu pendidikan di sekolah adalah proses belajar mengajar yang meliputi penggunaan metode mengajar oleh guru. Kemampuan siswa menerima materi pembelajaran di kelas sangat tergantung dari usaha guru dalam mengkondisikan kegiatan pembelajaran agar dapat menarik minat, perhatian siswa dan memancing kinerja pengetahuan siswa lebih lanjut. Salah satu upaya guru dengan menggunakan model pembelajaran dimana dalam sebuah model pembelajaran, banyak metode mengajar yang biasa digunakan secara bervariasi.

Dengan menerapkan model pembelajaran TGT, siswa akan terlihat lebih aktif, karena siswa akan diberikan permainan oleh guru dan bertanding melawan kelompok lain dengan mengejar skor terbanyak, sehingga siswa yang sebelumnya hanya menerima ceramahan dan catatan, maka dengan menggunakan model pembelajaran TGT siswa akan lebih giat dan aktif dalam belajar. Siswa dituntut untuk dapat memberikan sumbangan skor kepada kelompoknya dengan cara menjawab pertanyaanpertanyaan yang diberikan. Selain itu, melalui model pembelajaran kooperatif tipe TGT ini, siswa juga dapat belajar tentang rasa tanggung jawab dalam kelompok untuk ikut serta dalam kerja sama selama kegiatan turnamen berlangsung. Penerapan model pembelajaran TGT memungkinkan para siswa tidak akan merasa jenuh dan membuat siswa merasa lebih rileks dalam mengikuti setiap kegiatan pembelajaran. Oleh sebab itu siswa akan termotivasi untuk lebih aktif dalam kegiatan belajar mengajar sehingga prestasi siswa akan lebih meningkat.

\section{Kajian Hasil Penelitian yang Relevan}

Ada beberapa penelitian yang telah membuktikan bahwa model pembelajaran kooperatif tipe TGT dapat meningkatkan keaktifan dan hasil belajar siswa. Penelitian yang dilakukan oleh Wini Fitriani dan Suprih Widodo (2012) dengan judul penerapan pembelajaran kooperatif tipe TGT dalam meningkatkan kemampuan penalaran matematika siswa sekolah dasar. Penelitian ini mengangkat masalah pembelajaran matematika untuk mengetahui tingkat penalaran siswa dalam upaya memperbaiki hasil belajar sebelum, saat proses pembelajaran dan setelah penerapan pembelajaran kooperatif tipe TGT serta aktivitas siswa selama pembelajaran. Penelitian ini merupakan penelitian tindakan kelas (classroom action research) di kelas 5 SDN Subang yang terdiri dari tiga siklus. Pada setiap siklus terdiri dari perencanaan, pelaksanaan, observasi, refleksi dan review plan. Pengumpulan data dilakukan dengan cara observasi dan memberikan tes pada setiap siklus. Berdasarkan hasil tes dan observasi yang dilaksanakan dalam tiga siklus diperoleh data yang menunjukkan adanya hasil belajar dengan menerapkan pembelajaran kooperatif tipe TGT dalam meningkatkan penalaran matematika terlihat dari nilai rata-rata post test siswa diperoleh pada siklus I 65,38 , pada siklus II 73,64, dan siklus III 79,94. Dapat terlihat adanya peningkatan nilai ratarata siswa dari tiap siklus, sehingga dapat disimpulkan bahwa penerapan pembelajaran kooperatif tipe TGT dapat meningkatkan kemampuan penalaran matematika siswa Sekolah Dasar.

Penelitian yang dilakukan oleh Nola Susanti (2008) dengan judul penerapan model pembelajaran kooperatif tipe TGT 
dalam pembelajaran matematika SD. Berdasarkan hasil analisis data dan pembahasan yang telah dipaparkan, peneliti menyimpulkan bahwa pembelajaran menggunakan model pembelajaran kooperatif tipe TGT dapat meningkatkan aktivitas belajar pada pembelajaran matematika siswa kelas VA SDN 04 Metro Pusat. Ratarata persentase aktivitas belajar siswa pada siklus 1 dan siklus 2 mencapai $53,83 \%$ (cukup aktif) dan 66,72\% (aktif). Terjadi peningkatan sebesar $12,89 \%$ dari siklus 1 ke siklus 2. Kemudian pada siklus 3 ratarata persentase aktivitas siswa adalah $81,33 \%$ (sangat aktif), terjadi peningkatan sebesar $14,61 \%$ dari rata-rata persentase aktivitas siswa pada siklus 2 .

Berdasarkan kajian teori dan kajian hasil penelitian di atas, hipotesis tindakan penelitian ini adalah "melalui model pembelajaran kooperatif tipe Teams Games Tournament diduga dapat meningkatkan keaktifan dan hasil belajar matematika siswa kelas 5 di SD Virgo Maria 1 Ambarawa Semester II Tahun Pelajaran 2013 / 2014".

\section{METODE PENELITIAN}

Penelitian ini berupa Penelitian Tindakan Kelas (PTK) dengan menggunakan model PTK Kurt Lewin. Penelitian yang dilakukan terdiri dari 2 siklus. Tiap siklus terdiri dari 4 tahap, yaitu perencanaan, pelaksanaan tindakan, observasi, dan refleksi. Subjek penelitian ini adalah siswa kelas 5 SD Virgo Maria IAmbarawa yang berjumlah 26 siswa, yaitu 12 laki-laki dan 14 perempuan. Terdapat 2 variabel penelitian dalam penelitian ini yaitu: Variabel Bebas/Independen dan variabel terikat. Variabel independen dalam penelitian ini adalah model pembelajaran kooperatif tipe TGT. Yaitu, salah satu model pembelajaran yang menekankan pada struktur yang dirancang untuk mempengaruhi pola interaksi siswa dan memiliki tujuan untuk meningkatkan penguasaan akademik siswa. Variabel Terikat/dependen dalam penelitian ini adalah keaktifan dan hasil belajar Matematika. Keaktifan siswa dalam proses belajar mengajar akan mengakibatkan terbentuknya pengetahuan dan keterampilan yang akan mengarah pada peningkatan hasil belajar siswa pada mata pelajaran matematika.

Pengumpulan data menggunakan teknik tes dan non tes. Tes berbentuk soal pilihan ganda dan soal uraian dalam bentuk cerita. Tes ini diberikan kepada siswa untuk mengukur kemampuan siswa setelah dilaksanakannya pembelajaran kooperatif tipe TGT. Teknik non tes dalam penelitian ini adalah berupa pengamatan implementasi RPP, pengamatan aktivitas peserta didik dan penilaian proses (lembar observasi siswa dan guru).Pengamatan implementasi RPP digunakan untuk mendapat data tentang pengajaran guru di dalam kelas serta pengamatan keaktifan peserta didik, sehingga bisa dilihat di dalam pelaksanaan pembelajaran benar-benar sesuai dengan kondisi dan proses yang diharapkan. Pengamatan melalui diskusi kelompok dan kegiatan turnamen dilakukan terhadap proses pembelajaran dengan menggunakan model pembelajaran Teams Games Tournament (TGT). Dokumentasi digunakan untuk mendapatkan data tentang identitas dari peserta didik. Dalam hal ini data yang diperoleh adalah daftar peserta didik menonjol baik dari segi positif maupun negatifnya.

Penelitian ini dikatakan berhasil jika semua prosedur pembelajaran dengan menggunakan model pembelajaraan kooperatif tipe TGT dapat dilakukan seluruhnya dengan baik, sehingga kesulitan belajar yang dialami siswa selama ini dapat teratasi dan 
pada setiap akhir pokok bahasan serta akhir pelajaran berlangsung $80 \%$ siswa dapat memperoleh nilai yang mencapai atau melebihi KKM $(\geq 65)$ dan nilai rata-rata klasikal kelas juga mencapai KKM yang telah ditentukan $(\geq 65)$. Teknik analisis data dalam penelitian ini dilakukan dengan menggunakan teknik analisis ketuntasan dan komparatif, yaitu membandingkan nilai tes sebelum perbaikan, setelah siklus I dan setelah siklus II. Berdasarkan perbandingan nilai tersebut, juga akan dapat diketahui perbandingan ketuntasan klasikal sebelum perbaikan, setelah siklus I dan setelah siklus II.

\section{HASIL PENELITIAN DAN PEMBAHASAN}

\section{Kondisi Pra Siklus}

Sebelum siklus I dan siklus II dilaksanakan, peneliti terlebih dahulu melakukan observasi awal dengan tujuan mendapatkan data-data awal yang ada di lapangan. Datadata inilah yang nantinya akan digunakan oleh peneliti untuk menentukan tindakan yang harus dilakukan pada langkah-langkah selanjutnya.

Hasil observasi awal yang peneliti peroleh adalah bahwa hasil belajar siswa kelas 5 pada mata pelajaran matematika masih rendah dari KKM. Dari 26 siswa, 12 siswa sudah mencapai ketuntasan dan 14 siswa belum mencapai standar ketuntasan yang sudah ditetapkan yaitu 65. Rata-rata kelas yang di dapat sebelum diadakannya penelitian adalah 60,7. Hal ini disebabkan oleh tingkat pemahaman siswa yang masih kurang terhadap materi pelajaran. Cara mengajar guru juga terbilang masih konvensional. Guru belum mampu mengadakan inovasi pembelajaran seperti penggunaan metode-metode pembelajaran yang menarik dan sesuai dengan materi. Selain itu, siswa juga kurang aktif dalam mengikuti Kegiatan Belajar Mengajar (KBM) di kelas.

Itulah kenyataan yang ada di SD Virgo Maria 1 Ambarawa sebagai hasil observasi awal oleh peneliti yang nantinya akan digunakan sebagai dasar untuk menentukan tindakan yang peneliti lakukan pada langkah-langkah selanjutnya. Untuk mengetahui kejelasan nilai siswa kelas 5 pada pra siklus dapat dilihat pada tabel 1 .

Tabel 1 Rekapitulasi Rentang Nilai Pra Siklus Matematika Kelas 5 SD Virgo Maria 1 Ambarawa

\begin{tabular}{cccc}
\hline No & Rentang Nilai & Ketuntasan & Jumlah Siswa \\
\hline 1. & $20-34$ & Belum Tuntas & 3 \\
2. & $35-49$ & Belum Tuntas & 5 \\
3. & $50-64$ & Belum Tuntas & 6 \\
4. & $65-79$ & Tuntas & 4 \\
5. & $80-94$ & Tuntas & 8 \\
\hline & Jumlah & & 26 \\
\hline
\end{tabular}

\section{Analisis Hasil Penelitian}

Berdasarkan kondisi pra siklus tersebut, maka dirancang pembelajaran TGT dengan prosedur pelaksanaan penelitian tindakan kelas untuk meningkatkan keaktifan dan hasil belajar matematika siswa kelas 5. Di dalam penelitian yang akan dilaksanakan terdapat dua data yang harus diamati oleh peneliti yakni keaktifan dan hasil belajar matematika.

\section{Siklus I}

Dalam siklus I, tindakan yang dilakukan berupa penerapan model pembelajaran kooperatif tipe TGT. Dalam pelaksanaan tindakan, dibagi menjadi enam tahap. Tahap pertama, guru menyampaikan semua tujuan pembelajaran secara umum yang ingin dicapai yakni siswa dapat menggunakan pecahan dalam masalah perbandingan dan skala serta memotivasi siswa sebelum memulai penjelasan materi. Motivasi yang 
diberikan oleh guru berupa kegiatan-kegiatan apersepsi yang dapat menarik minat belajar siswa. Tahap kedua, guru menyajikan materi pelajaran secara umum kepada siswa dengan cara demonstrasi dan pemberian contoh soal kepada siswa. Selama proses pembelajaran ini, peneliti melakukan pengamatan tentang aktivitas belajar siswa dan guru yang mengajar. Tahap ketiga, guru membagi siswa menjadi beberapa kelompok secara heterogen, dimana masing-masing kelompok terdiri dari 4-5 orang. Tahap keempat, guru membagi siswa kedalam beberapa meja turnamen dan membimbing siswa dalam pelaksanaan kegiatan turnamen akademik tersebut. Tahap kelima, guru membagi soal evaluasi kepada siswa. Dalam mengerjakan soal evaluasi ini, siswa bekerja secara mandiri karena hasil dari evaluasi ini akan dijadikan sebagai sumber data hasil belajar individu tiap siswa. Tahap keenam, guru memberikan penghargaan kepada setiap anggota kelompok yang memiliki perolehan skor tertinggi. Diharapkan dengan ada penghargaan atau pemberian hadiah ini, dapat memotivasi siswa atau kelompok yang lain agar lebih giat belajar sehingga dapat memperoleh skor yang maksimal.

\section{a. Aktivitas Belajar Siswa}

Pengumpulan data tentang aktivitas dilaksanakan semenjak kegiatan awal berlangsung hingga kegiatan penutup pada penarikan kesimpulan secara bersamasama. Hasil pengamatan tentang aktivitas tersebut dicatat dan dilakukan pada setiap pertemuan siklus I. Kemudian dari data yang diperoleh, didapat data bahwa total skor aktivitas belajar siswa pada siklus I adalah 67 dengan rata-rata 3,2. Persentase aktivitas belajar siswa yang diperoleh sebesar 79,8\% dengan kriteria baik atau dikatakan sudah tergolong aktif. Namun pada hasil dta yang ada, masih terlihat dua aspek aktivitas belajar siswa yang dirasa kurang aktif yakni keaktifan siswa dalam mencatat materi pelajaran yang disampaikan oleh guru dan keaktifan siswa untuk bertanya kepada guru.

\section{b. Hasil Belajar Siswa}

Tes untuk evaluasi siklus I berupa soal berbentuk essay tentang pecahan sebagai perbandingan dan skala. Berdasarkan proses belajar mengajar dengan model pembelajaran kooperatif tipe TGT, didapat hasil belajar pada pertemuan I yang dapat dilihat pada tabel 2.

Tabel 2 Rekapitulasi Rentang Nilai Matematika Siklus I

Kelas 5 SD Virgo Maria 1 Ambarawa

\begin{tabular}{|c|c|c|c|c|c|}
\hline \multirow[b]{2}{*}{ No } & \multirow[b]{2}{*}{ Nilai } & \multicolumn{2}{|c|}{ Siklus I } & \multicolumn{2}{|c|}{ Keterangan } \\
\hline & & $\begin{array}{c}\text { Jumlah } \\
\text { Siswa }\end{array}$ & $\begin{array}{c}\text { Persentase } \\
(\%)\end{array}$ & Ketuntasan & Jumlah \\
\hline 1. & $29-40$ & 4 & 15,4 & Belum Tuntas & \multirow{4}{*}{14} \\
\hline 2. & $41-52$ & 6 & 23,1 & Belum Tuntas & \\
\hline 3. & $53-64$ & 4 & 15,4 & Belum Tuntas & \\
\hline 4. & $65-76$ & 3 & 11,5 & Tuntas & \\
\hline 5. & $77-88$ & 5 & 19,2 & Tuntas & \multirow{2}{*}{12} \\
\hline 6. & $89-100$ & 4 & 15,4 & Tuntas & \\
\hline \multicolumn{2}{|c|}{ Jumlah } & 26 & 100 & & \\
\hline \multicolumn{2}{|c|}{ Rata - rata } & \multicolumn{2}{|c|}{64,2} & & \\
\hline \multicolumn{2}{|c|}{ Nilai Tertinggi } & \multicolumn{2}{|c|}{100} & & \\
\hline \multicolumn{2}{|c|}{ Nilai Terendah } & \multicolumn{2}{|c|}{30} & & \\
\hline
\end{tabular}


Dari data hasil tes pada siklus I, dapat dilihat bahwa penerapan model pembelajaran kooperatif tipe TGT belum dapat dikatakan efektif karena masih banyak siswa yang belum tuntas dalam belajarnya $(\mathrm{KKM} \geq 65)$ yaitu sebanyak 14 siswa. Diketahui untuk nilai $29-40$ ada 4 siswa $(15,4 \%)$, nilai $41-52$ ada 6 siswa $(23,1 \%)$, nilai $53-64$ ada 4 siswa $(15,4 \%)$, nilai $65-76$ ada 3 siswa $(11,5 \%)$, nilai $77-88$ ada 5 siswa $(19,2 \%)$, dan nilai 89-100 ada 4 siswa $(15,4 \%)$. Nilai rata-rata kelas yang diperoleh 64,2, dengan nilai tertinggi adalah 100 dan nilai terendah adalah 30 .

Jika dibandingkan dengan kondisi pra siklus, dari segi rata-rata nilai klasikal sudah terdapat peningkatan hasil belajar siswa yakni dari 60,7 menjadi 64,2. Akan tetapi jika dilihat dari segi persentase ketuntasan belum dapat dikatakan adanya peningkatan. Hal ini dapat dilihat dari jumlah presentase ketuntasan pada pra siklus dan siklus I masih sama, yaitu 53,8\% siswa belum tuntas dan $46,2 \%$ siswa tuntas.

Setelah diadakannya evaluasi dan refleksi pada siklus I, masih ada 14 siswa yang perlu ditingkatkan hasil belajarnya karena masih memiliki nilai di bawah 65 . Hal ini diduga karena siswa belum terbiasa dengan penerapan pembelajaran inovatif seperti TGT sehingga siswa masih kebingungan, masih ada beberapa siswa yang belum mampu menguasai materi pembelajaran yang diberikan oleh guru dan masih ada siswa yang belum aktif dalam proses pembelajaran di kelas. Oleh karena itu, penelitian ini masih perlu dilanjutkan pada siklus II.

\section{Siklus II}

Tahap pelaksanaan pembelajaran pada siklus II masih sama dengan tahap pelaksanaan siklus I. Namun pada siklus II ini, materi yang akan dipelajari adalah sifat- sifat bangun datar. Hal yang membedakan dengan tindakan pada siklus I adalah adanya penekanan pada aktivitas belajar siswa, pendalaman materi yang diajarkan, pengorganisasian siswa dalam kelompok, penguasaan kelas, dan pelaksanaan turnamen akademik.

\section{a. Aktivitas Belajar Siswa}

Hasil pengamatan aktivitas belajar siswa pada siklus II dengan menerapkan model pembelajaran kooperatif tipe TGT mengalami peningkatan. Hal tersebut dapat dilihat dari total skor yang diperoleh pada siklus II adalah 76 dengan rata-rata 3,6. Persentase yang diperoleh sebesar 90,5\% dengan kriteria sangat baik. Pada siklus II ini siswa sudah mulai aktif untuk mencatat halhal penting pada materi pelajaran yang diajarkan oleh guru. Selain itu, siswa sudah mulai aktif bertanya kepada guru apabila ada bagian dari materi yang belum dipahami oleh siswa. Peningkatan keaktifan pada siklus II ini adalah sebagai hasil perbaikan yang dilakukan guru pada siklus I yang sudah dilaksanakan sebelumnya.

b. Hasil Belajar Siswa

Hasil belajar siswa pada siklus II setelah diterapkannya model pembelajaran kooperatif tipe TGT juga mengalami peningkatan. Perolehan hasil evaluasi pada siklus II ini dapat dilihat pada tabel 3.

Dari tabel 3 dapat dilihat bahwa jumlah siswa yang mendapat nilai 29-40 hanya ada 1 siswa dengan persentase $3,8 \%$, nilai $41-52$ ada 1 siswa dengan persentase 3,8\%, nilai 53-64 sebanyak 8 siswa dengan persentase $30,8 \%$, nilai $65-76$ ada 4 siswa atau $15,4 \%$, nilai $77-88$ ada 4 siswa atau $15,4 \%$, dan nilai $89-100$ sebanyak 8 siswa dengan persentase 30,8\%. Dari 26 siswa, ada 10 siswa yang belum mencapai batas 
Tabel 3 Rekapitulasi Rentang Nilai Matematika Siklus II Kelas 5 SD Virgo Maria 1 Ambarawa

\begin{tabular}{|c|c|c|c|c|c|}
\hline \multirow[b]{2}{*}{ No } & \multirow[b]{2}{*}{ Nilai } & \multicolumn{2}{|c|}{ Siklus II } & \multicolumn{2}{|c|}{ Keterangan } \\
\hline & & $\begin{array}{l}\text { Jumlah } \\
\text { Siswa }\end{array}$ & $\begin{array}{c}\text { Persentase } \\
(\%)\end{array}$ & Ketuntasan & Jumlah \\
\hline 1. & $29-40$ & 1 & 3,8 & Belum Tuntas & \\
\hline 2. & $41-52$ & 1 & 3,8 & Belum Tuntas & 10 \\
\hline 3. & $53-64$ & 8 & 30,8 & Belum Tuntas & \\
\hline 4. & $65-76$ & 4 & 15,4 & Tuntas & \\
\hline 5. & $77-88$ & 4 & 15,4 & Tuntas & 16 \\
\hline 6. & $89-100$ & 8 & 30,8 & Tuntas & \\
\hline \multicolumn{2}{|c|}{ Jumlah } & 26 & 100 & & \\
\hline \multicolumn{2}{|c|}{ Rata - rata } & \multicolumn{2}{|c|}{74,5} & & \\
\hline \multicolumn{2}{|c|}{ Nilai Tertinggi } & \multicolumn{2}{|c|}{100} & & \\
\hline \multicolumn{2}{|c|}{ Nilai Terendah } & \multicolumn{2}{|r|}{40} & & \\
\hline
\end{tabular}

KKM ( $\geq 65)$ sehingga dapat dikatakan belum tuntas belajar. Sedangkan 16 siswa yang mendapatkan nilai di atas 65 dikatakan tuntas belajar karena sudah melebihi batas ketuntasan minimal. Nilai rata-rata kelas 74,5 dengan nilai terendah 40 dan nilai tertinggi adalah 100 .

Dilihat dari presentase ketuntasan belajar siswa dan perolehan nilai matematika siswa kelas 5 siklus II dapat diketahui bahwa siswa yang memiliki nilai $\leq 65$ sebanyak 10 siswa dengan persentase $38,5 \%$, sedangkan yang sudah mencapai KKM sebanyak 16 siswa dengan persentase $61,5 \%$. Berbeda dengan kondisi pra siklus dan siklus I dimana persentase ketuntasan siswa hanya diperoleh $53,8 \%$ siswa tidak tuntas dan 46,2\% siswa tuntas. Untuk dapat melihat perbandingan perolehan hasil belajar matematika siswa kelas 5 dengan lebih jelas, dapat dilihat pada gambar 1 .

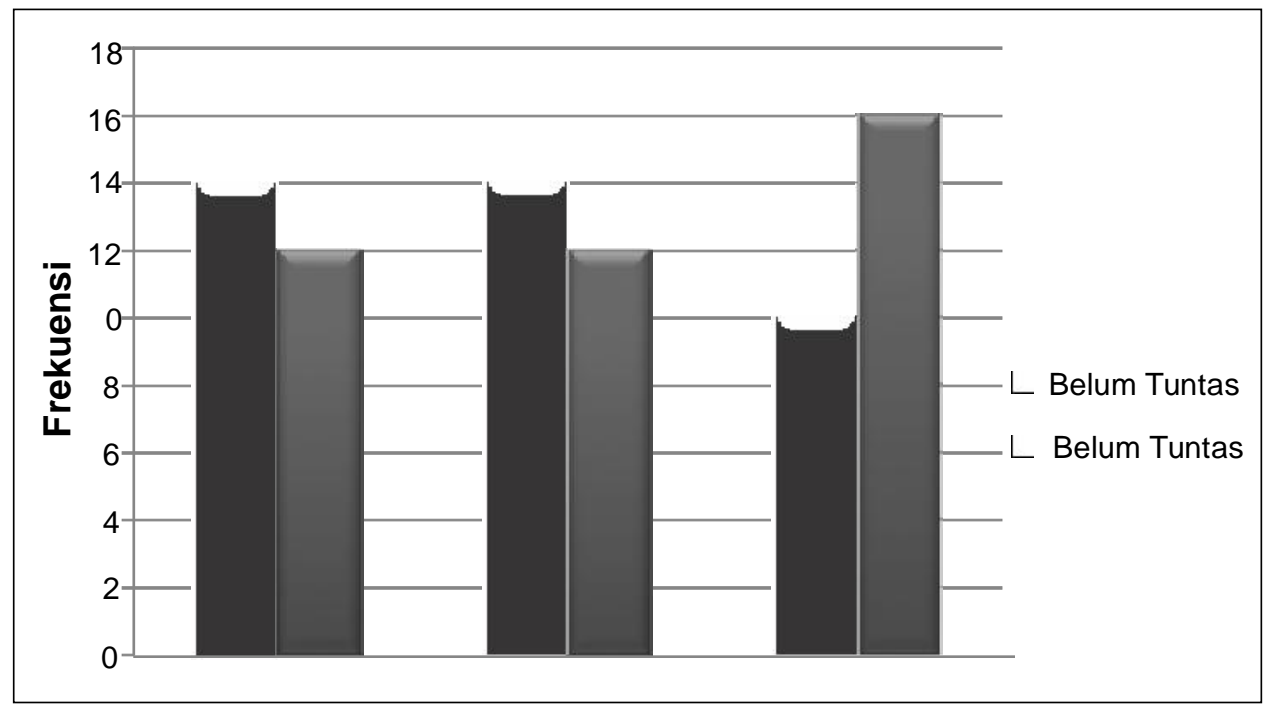

Gambar 1 Diagram Rekapitulasi Nilai Matematika Pra Siklus, Siklus I, dan Siklus II Siswa Kelas 5 


\section{Pembahasan}

Pelaksanaan pembelajaran matematika dengan model pembelajaran kooperatif tipe TGT sesuai sintaks dalam penelitian ini dapat memperbaiki dan meningkatkan keaktifan dan hasil belajar matematika siswa kelas 5 SD Virgo Maria 1 Ambarawa. Hal ini dapat dilihat dari adanya peningkatan perolehan skor dan persentase aktivitas belajar siswa yang mengalami peningkatan dari siklus I ke siklus II. Pada siklus I total skor aktivitas belajar siswa yang diperoleh berjumlah 67 dengan rata-rata 3,2. Persentase aktivitas pada siklus I yaitu 79,8\% . Setelah dilakukan perbaikan pada siklus II, total skor yang diproleh yaitu 76 dengan rata-rata 3,6. Persentase aktivitas belajar pun meningkat menjadi 90,5\%. Hasil belajar matematika yang diperoleh siswa juga mengalami peningkatan. Pada pra siklus atau sebelum diterapkannya model pembelajaran kooperatif tipe TGT, jumlah siswa yang tidak tuntas sebanyak 14 siswa $(53,8 \%)$ dan 12 siswa tuntas $(46,2 \%)$ dengan nilai rata-rata klasikal 60,7. Pada siklus I jumlah siswa yang sudah tuntas dan yang tidak tuntas masih sama dengan jumlah pada kondisi pra siklus, namun rata-rata klasikal yang diproleh mengalami peningkatan yakni 64,2 . Hal ini terjadi karena adanya kemungkinan pada penerapan model pembelajaran kooperatif tipe TGT ini masih membuat para siswa mengalami kebingungan atau belum optimalnya guru dalam menerapkan model pembelajaran tersebut. Pada siklus II jumlah siswa yang tidak tuntas ada 10 siswa $(38,5 \%)$ dan yang sudah tuntas ada 16 siswa $(61,5 \%)$ dengan rata-rata 74,5.

Jika dilihat dari segi persentase yang ada, pembelajaran dengan model pembelajaran kooperatif tipe TGT ini belum dikatakan efektif atau berhasil. Hal ini disebabkan karena persentase yang diperoleh pada akhir siklus II belum sesuai dengan indikator keberhasilan yang ingin dicapai yaitu $80 \%$ siswa mendapat nilai lebih dari 65. Yang menjadi faktor dari permasalahan tersebut adalah karena pada sekolah tersebut khususnya di kelas 5, tidak terbiasa dengan penerapan model pembelajaran yang inovatif. Bagi mereka model pembelajaran tersebut menjadi suatu hal yang baru. Meskipun pada saat pelaksanaan pembelajaran tersebut suasana menjadi aktif dan menyenangkan, namun hasil belajar yang diperoleh siswa belum cukup memenuhi persentase ketuntasan yang diharapkan. Pada akhir siklus II, persentase ketuntasan yang dipeoleh hanya $61,5 \%$ dari $80 \%$ yang diharapkan. Untuk mengatasi hal tersebut, tetap diadakan upaya perbaikan dalam pembelajaran yaitu akan ada penanganan lebih lanjut oleh guru kelas yang bersangkutan.

\section{SIMPULAN DAN SARAN}

\section{Simpulan}

Penerapkan model pembelajaran kooperatif tipe Teams Games Tournament (TGT) dapat meningkatkan keaktifan dan hasil belajar matematika siswa kelas 5 SD Virgo Maria 1 Ambarawa semester II tahun pelajaran 2013/ 2014. Hal tersebut dapat dilihat dari perolehan skor aktivitas belajar siswa kelas 5 yang mengalami peningkatan. Skor awal aktivitas belajar siswa pada siklus I adalah 67 dengan rata-rata 3,2 (79,8\%); pada siklus II meningkat menjadi 76 dengan rata-rata 3,6 (90,5\%). Selain itu, hasil belajar matematika yang diperoleh siswa kelas $5 \mathrm{SD}$ Virgo Maria 1 Ambarawa mengalami peningkatan. Rata-rata kelas pada tes awal 60,7, tes siklus I 64,2, dan tes siklus II menjadi 
74,5 . Untuk siswa tuntas belajar, pada tes awal 46,15\%, siklus I 46,15\%, dan pada siklus II sebanyak 61,5\% dengan KKM $\geq 65$. Ini berarti dari segi persentase ketuntasan belum dapat memenuhi indikator kinerja yang diharapkan yaitu siswa tuntas dengan persentase $80 \%$.

\section{Saran}

Bagi sekolah, agar membantu memfasilitasi penerapan model pembelajaran kooperatif tipe TGT dalam rangka meningkatkan kemampuan belajar siswa. Bagi guru: (a) sebelum dilaksanakannya proses pembelajaran, hendaknya guru membuat Rencana Pelaksanaan Pembelajaran (RPP) serta mempersiapkan media pembelajaran yang sesuai dengan tujuan yang ingin dicapai, (b) sebelum menggunakan model pembelajaran tipe TGT di kelas sebaiknya guru mendalami secara benar mengenai model pembelajaran tersebut, dengan mempelajari sintaks dan aktivitas pembelajaran yang terkandung di dalamnya agar tidak ada kesalahan dalam penggunaannya sehingga berdampak pada hasil belajar dan aktivitas yang berlangsung di kelas, (c) Untuk meningkatkan keaktifan siswa dan hasil belajar matematika guru diharapkan dapat menerapkan model pembelajaran kooperatif tipe TGT karena terdapat permainan atau turnamen akademik yang sangat menarik sehingga siswa tidak merasa jenuh.

Bagi siswa: (a) siswa hendaknya dapat berperan aktif dengan menyampaikan ide atau pemikiran pada proses pembelajaran sehingga proses pembelajaran dapat berjalan dengan lancar dan memperoleh hasil belajar yang optimal, (b) Bagi siswa yang memiliki karakter sering ramai dan tidak memperhatikan sebaiknya diberikan motivasi khusus yaitu memberikan perhatian lebih dan memberikan arahan agar mau belajar dan tidak mengganggu temannya saat kegiatan belajar mengajar berlangsung.

\section{DAFTAR PUSTAKA}

Badan Standar Nasional Pendidikan Kurikulum SD dan MI. 2008. Jakarta: Depdiknas.

Fitriani, Wini dan Widodo, Suprih. 2011. Penerapan Pembelajaran Kooperatif Tipe Teams Games Tournaments (TGT) Dalam Meningkatkan Kemampuan Penalaran Matematika Siswa Sekolah Dasar (Penelitian Tindakan Kelas Pada Pokok Bahasan Pengukuran Volume di Kelas V SDN Jl. Palabuan Kecamatan Subang.

Herlina. 2013. Penggunaan Model Pembelajaran Kooperatif Tipe TGT Untuk Meningkatkan Aktivitas dan Pemahaman Konsep Matematika. Bandar Lampung: UNILA.

Huda, Mitahul. 2013. Cooperative Learning. Jakarta: Pustaka Belajar.

Isjoni. 2009. Pembelajaran Kooperatif. Yogyakarta: Pustaka Belajar.

Lie, Anita. 2002. Cooperative Learning. Jakarta: Grasindo.

Mulkiah, dkk. 2013. Penerapan Pembelajaran Kooperatif Tipe TGT untuk Meningkatkan Aktivitas dan Prestasi Belajar Matematika. Lampung: UNILA. (http://jurnal.fkip.unila.ac.id/ index.php/MTK/article/view/1461, 29 Desember 2013)

Slavin, Robert E. 2005. Cooperative Learning, Teori, Riset dan Praktik. Bandung: Nusa Media.

Slameto. 1995. Belajar dan Faktor-faktor yang Mempengaruhinya. Jakarta: Rineka Cipta. 
Sugiono. 2010. Penelitian Pendekatan

Kuantitatif, Kualitatif dan $R \& D$. Bandung: Alfabeta.
Suprijono, Agus. 2011. Cooperative Learning. Yogyakarta: Pustaka Belajar.

Zainal, Aqib. 2011. Penelitian Tindakan Kelas. Bandung: CV Yrama Widya. 